\title{
Effect of Maize (Zea mays.L) on Bean (Phaseolus vulgaris L.) Yield and its Components in Maize- Bean Intercropping
}

\author{
Addisu Getahun ${ }^{1}$, Seltene Abady ${ }^{2}$ \\ ${ }^{1,2}$ Crop Researcher (Plant Breeding \&Genetics), Ethiopian Institute of Agricultural Research, Pawe Research Center, Ethiopia
}

\begin{abstract}
This study was carried out to determine the performance of haricot bean varieties in the intercropping with maize hybrid. It was designed as RCBD design having three replications. The experimental materials were including 4 haricot bean varieties (Awash Melka, Awash-1, Dimtu and Nasir) and one maize hybrid (BH-540). Analysis result revealed that there is a significant difference among the haricot bean for the grain yield in the over all of two locations. It also showed that all the varieties showed comparative yield advantage if they will be intercropped with maize hybrid (BH-540) than the sole cropping system. The highest land equivalent ration was obtained by Dimtu (1.64). This indicated that $64 \%$ more efficient to use Dimtu in the intercropping with BH-540 hybrid than the sole cropping system. Moreover, the relative yield advantage for Dimtu in the intercropping obtained $5817 \mathrm{~kg} / \mathrm{ha}$. It can be drawn a conclusion that using of intercropping system for the varieties used in the study will have yield advantage than the sole cropping system. The bean varieties which were intercropped with maize hybrid showed significant different for most of the traits such as days to flowering, Plant height, number of pods per plant, number of seeds per plant and hundred seed weight. But all of the traits for Maize showed no significant difference for all varieties in the intercropping as well as for the sole one. This indicates that bean yield in the intercropping varies with the bean varieties used. Therefore, it is important to find a compatible variety of bean to increase production in the bean- maize intercropping.
\end{abstract}

Keywords: Haricot bean, Maize, intercropping, Economic Grain yield, Northwestern Ethiopia

\section{Introduction}

Intercropping consists of simultaneous culture of two or more crops in the same field in order to reach land equivalent ratios that show nature prefers multiple species rather than single species [1], [2]. It has been traditionally practiced in many parts of the world [3], [4] and has some advantages over monocultures [4]. Intercropping supplies efficient resource utilization, reduces risk to the environment and production costs, and provides greater financial stability, making the system more suitable particularly for laborintensive, small farmers [3]. Intercropping presents a large level of risk reduction for the smallholder. If one crop is entirely lost to pest or drought damage, the farmer may still harvest the other crop in the field. Given the unpredictable rainy season and the different water requirements of each crop, planting many varieties of the same crop in an intercropped field gives the farmer a better chance that some crops will survive [5]. Regarding to increasing growth of the world population, demolition and overthrown of ecological balance of the systems, it is of a great importance to increase agricultural products and environmental preservation. Intercropping is considered one of the methodologies used to achieve this goal [6], [7].

Growing crops in mixture is the main feature of the traditional cropping systems of the tropics [8]. Recent research findings have shown that mixed cropping shall continue to be more profitable than sole cropping for the small scale or peasant farmers in the tropics, since it provides security in food output which is considered more important than food maximization in the developing world [9]
Spatial arrangement of intercrops is an important management practice that can improve radiation interception through more complete ground cover. There is, therefore, potential for higher productivity of intercrops when intraspecific competition is less than inter-specific competition for a limiting resource such as solar radiation or nutrients. Much of the poor crop yields obtained in the developing countries may be attributed in part to improper crop arrangement with its attendant waste of environmental resources and wrong intra-specific mixtures [10]. Research suggests that a biological advantage to intercropping may result from complementary use of growth resources. Component crops may differ in their use of growth resources over time and space such that when grown together they make more efficient use of light, water, and nutrients than when grown separately. In addition, competition from weeds may be lessened by a combination of crop species occupying two or more niches in the field [11],[12] hypothesized that intercropping exhibited biological advantages over sole cropping when inter-specific competition for growth resources was less than intra-specific competition.

Farmers in the Benishangule gumze have traditionally used maize-bean intercropping for food production. However, little is known about the effect of competition between the species on physio- agronomic attributes of maize and bean. Therefore the present study was conducted to evaluate the potential of haricot bean varieties for their intercropping with maize hybrid.

\section{Materials and Methods}

\section{Description of the Study Area}

The experiment was conducted in Pawe Agricultural Research Center Pawe District $\left(11^{0} 18^{\prime} \mathrm{N}\right.$ and $\left.036^{\circ} 24^{\prime} \mathrm{E}\right)$ 


\section{International Journal of Science and Research (IJSR) \\ ISSN (Online): 2319-7064 \\ Index Copernicus Value (2013): 6.14 | Impact Factor (2014): 5.611}

Metekel Zone Benishangule Gumuze National Regional State Northwestern Ethiopia in 2013 main- cropping season. Pawe is found 573 kilometers away from Addis Ababa. The topography is slightly undulating from hill-tops towards rivers. The altitude of the area ranges between $1000-1200$ m.a.s.l. The soils are broadly categorized as Vertisols which account for $40-45 \%$ of the area; Nitisols which account for $25-30 \%$; and intermediate soils of a blackish brown color, which account for $25-30 \%$. . The specific soil type of the site is well drained Nitosol with the $\mathrm{pH}$ value ranging from 5.3 to 5.5. Besides, Pawe district is well known for its high and torrential rainfall with a unimodal rainfall pattern that extends from May to October. The area receives an intensive rainfall amounting to $1860.3 \mathrm{~mm}$. The mean annual maximum and minimum temperatures are 32.6 and $16.5^{\circ} \mathrm{C}$ respectively (Source: PARC). And also this activity was conducted at Dibatie District which is the same methodology \& cropping season. The Dibatie district is located in Metekel zone $105 \mathrm{~km}$ away from Pawe, $78 \mathrm{~km}$ from Gilgel Beles; $547 \mathrm{~km}$ away from Addis Ababa and the soil of experimental area is nitosol. The altitude of this experimental site is 1400 meter above sea level. The climate is tropical hot humid with an annual rainfall ranging from 850 to $1200 \mathrm{~mm}$ concentrated from May to October, with the average temperature of $25^{\circ} \mathrm{c}$. Both of these two locations are categorized among the most maze and haricot bean producing area in the Benishangule gumze region.

Table 1: Description of haricot bean varieties and maize hybrid use in the experiment

\begin{tabular}{|l|l|l|l|}
\hline no & variety /hybrid & Release by & year of release \\
\hline 1 & Awash Melka & MARC/EIAR & 1990 \\
\hline 2 & Awash-1 & MARC/EIAR & 1990 \\
\hline 3 & Nasir & MARC/EIAR & 2003 \\
\hline 4 & Dimtu & MARC/EIAR & 2003 \\
\hline 5 & BH-540 (maize) & BARC/EIAR & 1995 \\
\hline
\end{tabular}

Source: [13]. MARC=Melkassa Agricultural Research Center, EIAR= Ethiopian Institute of Agricultural Research, BARC=Bako Agricultural Research Center

\section{Experimental Design \& Methods of Data Collection}

The experimental design was planed as RCBD design with 3 replications having the plot size $4 \mathrm{mx} 3.75 \mathrm{~m}$, the experimental materials were including 4 haricot bean varieties (Awash Melka, Awash-1, Dimtu and Nasir) and one maize hybrid (BH-540). All the recommended agronomic practices were followed during the course of experimentation. Data like days to $50 \%$ flowering (DF), days to $95 \%$ maturity (DM), Plant number of pods per plant (NPP), number of seeds per plant (NSPP), number of seeds per pod (NSPP) and hundred seed weight (HSW) were collected specifically for haricot bean and the data which were collected for maize such as stand count at harvest, number of cobs at harvest and field weight. Data such as height $(\mathrm{PH})$, stand count at harvest $(\mathrm{SCH})$ and adjusted grain yield (AGY) were collected for both crops. Seed yield per plot was measured in grams after moisture of the seed was adjusted to $12.5 \%$ for haricot bean and $10 \%$ for maize crop.

\section{Data Analysis}

The Land Equivalent Ratio - LER is considered to be one of the most appropriate indices to evaluate the efficiency of intercropping system in producing better yields as compared with yields in sole cropping. The index was used to assess maize-bean intercropping advantages relative to sole cropping [14]. LER defined as the land area required as sole crops to produce the same yields as Inter-Cropping and it was determined according to the equation below as stated by [15].

$$
\mathrm{LER}=\mathrm{LA}+\mathrm{LB}=\frac{\mathrm{YA}}{\mathrm{SA}}+\frac{\mathrm{YB}}{\mathrm{SB}}
$$

Where LA and LB are the LER's for individual crops, (called partial LER's) and YA and YB are the individual crop yields in intercropping, where SA and SB are their yields as sole crops. The partial LERs are then summed up to give the total LER for the intercrop. Land equivalent ratio (LER) is also the amount of sole-cropped land required to produce the same yields as one unit of intercropped land.

All the data collected were subjected to statistical analysis software appropriate to RCBD design in a randomized complete block using SAS soft ware (version, 9.0). Analyses of variance (ANOVA) were constructed to examine competition effect between component crop maize and haricot bean and its interaction on the variables measured. Treatment and location means were separated and compared using Duncan's Multiple Range Test (DMRT) at $\mathrm{P}<5 \%$ probability level [16].

Table 2: RCBD analysis of variance and expected mean square

\begin{tabular}{|c|c|c|c|}
\hline Source of variation & $D f$ & Mean square & $\begin{array}{c}\text { Expected } \\
\text { mean square }\end{array}$ \\
\hline Replication & $\mathrm{r}-1$ & $\mathrm{Ms}_{\mathrm{r}}$ & $\sigma^{2} \mathrm{e}+\mathrm{g} \sigma_{\mathrm{r}}^{2}$ \\
\hline Genotypes/treatments & $\mathrm{g}-1$ & $\mathrm{Ms}_{\mathrm{g}}$ & $\sigma^{2}{ }_{\mathrm{e}}+\mathrm{r}^{2}{ }_{\mathrm{g}}$ \\
\hline Error & $(\mathrm{r}-1)(\mathrm{g}-1)$ & $\mathrm{Ms}_{\mathrm{e}}$ & $\sigma_{\mathrm{e}}^{2}$ \\
\hline
\end{tabular}

Where, $\mathrm{r}=$ number of replications; $\mathrm{ms}_{\mathrm{r}}=$ mean square due to replications; $\mathrm{g}=$ number of genotypes; $\mathrm{ms}_{\mathrm{g}}=$ mean square due to genotypes; $\mathrm{ms}_{\mathrm{e}}=$ mean square of error; $\sigma_{\mathrm{g}}^{2}, \sigma_{\mathrm{r}}^{2}$ and $\sigma^{2}$ ere variances due to genotype, replication and error, respectively.

RCBD ANOVA was computed using the following model:

$Y_{i j}=\mu+r_{j}+g_{i}+\varepsilon_{i j}$

Where, $\mathrm{Y}_{\mathrm{ij}}=$ the response of trait $\mathrm{Y}$ in the $\mathrm{i}^{\text {th }}$ genotype and the $\mathrm{j}^{\text {th }}$ replication

$\mu=$ the grand mean of trait $Y$

$r_{j}=$ the effect of the $j^{\text {th }}$ replication

$\mathrm{g}_{\mathrm{i}}=$ the effect of the $\mathrm{i}^{\text {th }}$ genotype

$\varepsilon_{\mathrm{ij}}=$ experimental error effect.

\section{Results and Discussion}

The result revealed that Awash melka intercrop with maize BH-540 scores $(15 \mathrm{~cm})$ height and its sole records $(25 \mathrm{~cm})$, this implies that the competition between haricot bean and maize is very high; as we observe the plant height of haricot bean intercrop with maize and it's; sole crops longer height than intercrops. There is a significance difference between treatments in the traits of plant height, days to $50 \%$ flowering; number of pods per plant, seeds per plant and hundred seed weight, but other agronomic traits has no significance difference among treatments. In general the result showed that there was high competition between 


\section{International Journal of Science and Research (IJSR) \\ ISSN (Online): 2319-7064 \\ Index Copernicus Value (2013): 6.14 | Impact Factor (2014): 5.611}

maize and haricot bean. The grain yield product indicated that sole crops score good yield than mixed crops; but Dimtu and Nassir scores maximum yield (665kg/ha) and $(631 \mathrm{~kg} / \mathrm{ha})$ in intercropping than sole crops $(631 \mathrm{~kg} / \mathrm{ha})$ and

Table 3: Mean values for the traits of haricot bean in the bean-maize intercropping at Pawe on station

\begin{tabular}{|c|c|c|c|c|c|c|c|c|c|}
\hline Treatments & Plht & Sch & df & dm & nppp & nspp & spp & hsw & AGY(kg/ha) \\
\hline A.Melka vs BH-540 & $15 \mathrm{e}$ & $266 \mathrm{a}$ & 45 a & $70 \mathrm{a}$ & $2.4 \mathrm{bc}$ & $4 \mathrm{a}$ & $6.8 \mathrm{bc}$ & $15 \mathrm{ab}$ & $432 \mathrm{a}$ \\
\hline Awash-1 vs BH-540 & $27 \mathrm{~cd}$ & 230 a & $36 \mathrm{~b}$ & 63 a & $1.7 \mathrm{c}$ & $3 \mathrm{a}$ & $6 \mathrm{bc}$ & $16 \mathrm{ab}$ & $452 \mathrm{a}$ \\
\hline Dimitu vs BH-540 & $30.6 \mathrm{~cd}$ & $233 \mathrm{a}$ & $40 \mathrm{ab}$ & $64 \mathrm{a}$ & $2.3 \mathrm{bc}$ & 5 a & $7 \mathrm{bc}$ & 18.67 a & 665 a \\
\hline Nassir vs BH-540 & $21 \mathrm{de}$ & $265 \mathrm{a}$ & $37 \mathrm{ab}$ & $64 \mathrm{a}$ & $1.5 \mathrm{c}$ & $3 \mathrm{a}$ & $4 \mathrm{c}$ & 19 a & $631 \mathrm{a}$ \\
\hline Awash melka & 25 cde & 287 a & $40 \mathrm{ab}$ & $67 \mathrm{a}$ & $4.9 \mathrm{ab}$ & $4 \mathrm{a}$ & 23 a & $15 \mathrm{ab}$ & $634 a$ \\
\hline Awash-1 & 45 a & $242 \mathrm{a}$ & $36 \mathrm{~b}$ & $65 \mathrm{a}$ & $5.5 \mathrm{a}$ & 5 a & 19 a & $11 \mathrm{~b}$ & $627 \mathrm{a}$ \\
\hline Dimitu & 35 bc & $265 \mathrm{a}$ & $40 \mathrm{ab}$ & $71 \mathrm{a}$ & $3.6 \mathrm{abc}$ & $5 \mathrm{a}$ & $15 a b$ & $17 \mathrm{ab}$ & $631 \mathrm{a}$ \\
\hline Nassir & $45 \mathrm{ab}$ & 300 a & $36 \mathrm{~b}$ & $66 \mathrm{a}$ & $5.9 \mathrm{a}$ & $4 \mathrm{a}$ & 20 a & $16 \mathrm{ab}$ & $627 \mathrm{a}$ \\
\hline CV(\%) & 19.90 & 23.89 & 6.21 & 6.21 & 45.80 & 35.76 & 44.27 & 23.23 & 27.93 \\
\hline LSD $(\mathrm{P}<5 \%)$ & 10.99 & 109.21 & 4.22 & 7.19 & 2.79 & 2.60 & 9.90 & 6.52 & 286.81 \\
\hline Mean & 31.56 & 261.00 & 38.79 & 66.2 & 3.48 & 4.17 & 12.78 & 16.04 & 586.32 \\
\hline
\end{tabular}

Where Trt=treatment, plht=plant height, sce=standcount at emergence, $\mathrm{df}=$ days to flowering, $\mathrm{dm}=$ days to maturity, nppp=number of pods per plant, nspp=number of seeds per pod, spp=seeds per plant, hsw $=$ hundred seed weight, mc= moisture content, AGY=adjusted grain yield. Means with the same letter are not significantly different

The ANOVA result for the combination of the locations showed that the sole cropping haricot bean varieties scored longer heights than Intercropping due to growth limitation factor like light intensity, moisture, air penetration etc maize acting as a shade and suppressed beans growth. There is significance differences observed from plant height, days to flowering, days to maturity, and number of pods per plant, (627kg/ha) respectively. Dimtu and Nassir varieties were good for intercropping ability in Pawe area (table 3). number of seeds per pod, seeds per plant, hundred seed weight and Grain yields; but there is no significance difference among stand count at harvest. As we focus on the overall grain yield results .Nassir scores good yield (500kg/ha) in intercrop and $(1001 \mathrm{~kg} / \mathrm{ha})$ in sole cropping; this implies that good preferable genetic performance for intercropping than sole cropping cultures in overall locations of Pawe and Dibatie districts. The reason for the lower maize and haricot bean yields among the intercrops concerning the smaller sowing distances within the row was the enhanced interspecies and intra-species competition for the basic factors (table 4).The following picture: 1 shows haricot bean-maize intercropping
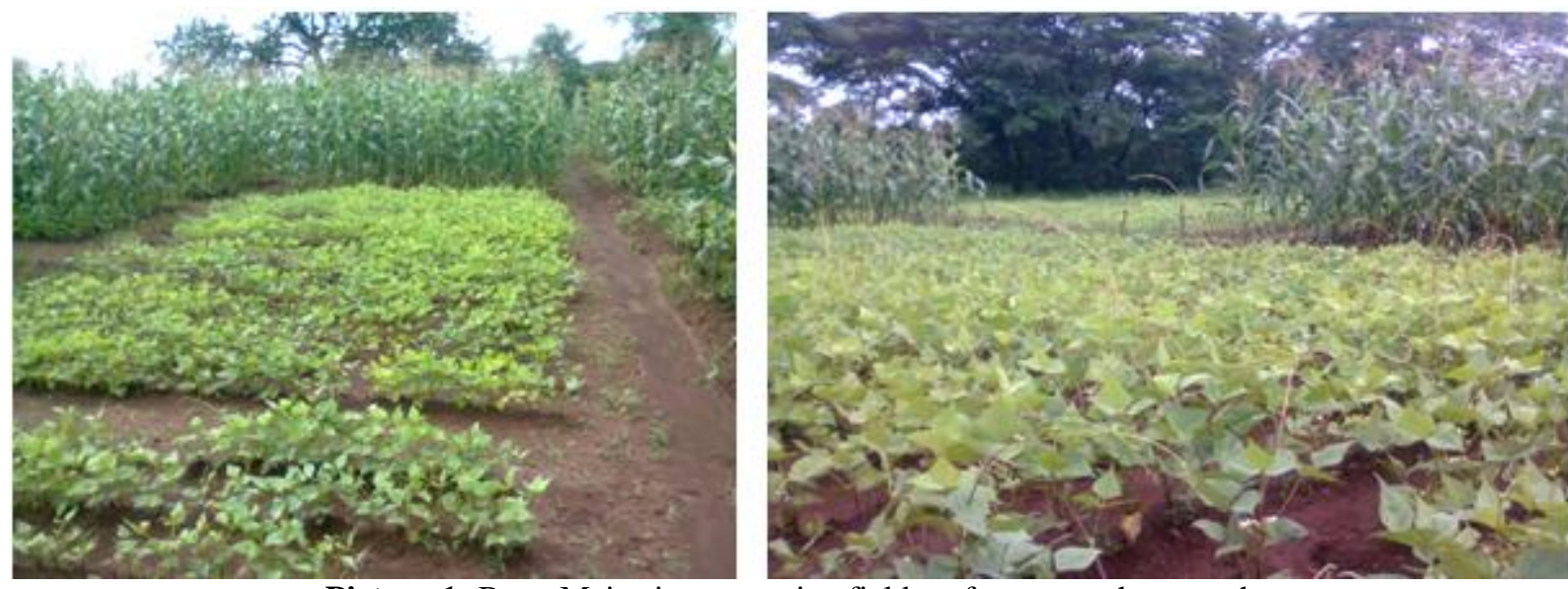

Picture 1: Bean-Maize intercropping field performance photograph 
International Journal of Science and Research (IJSR)

ISSN (Online): 2319-7064

Index Copernicus Value (2013): 6.14 | Impact Factor (2014): 5.611

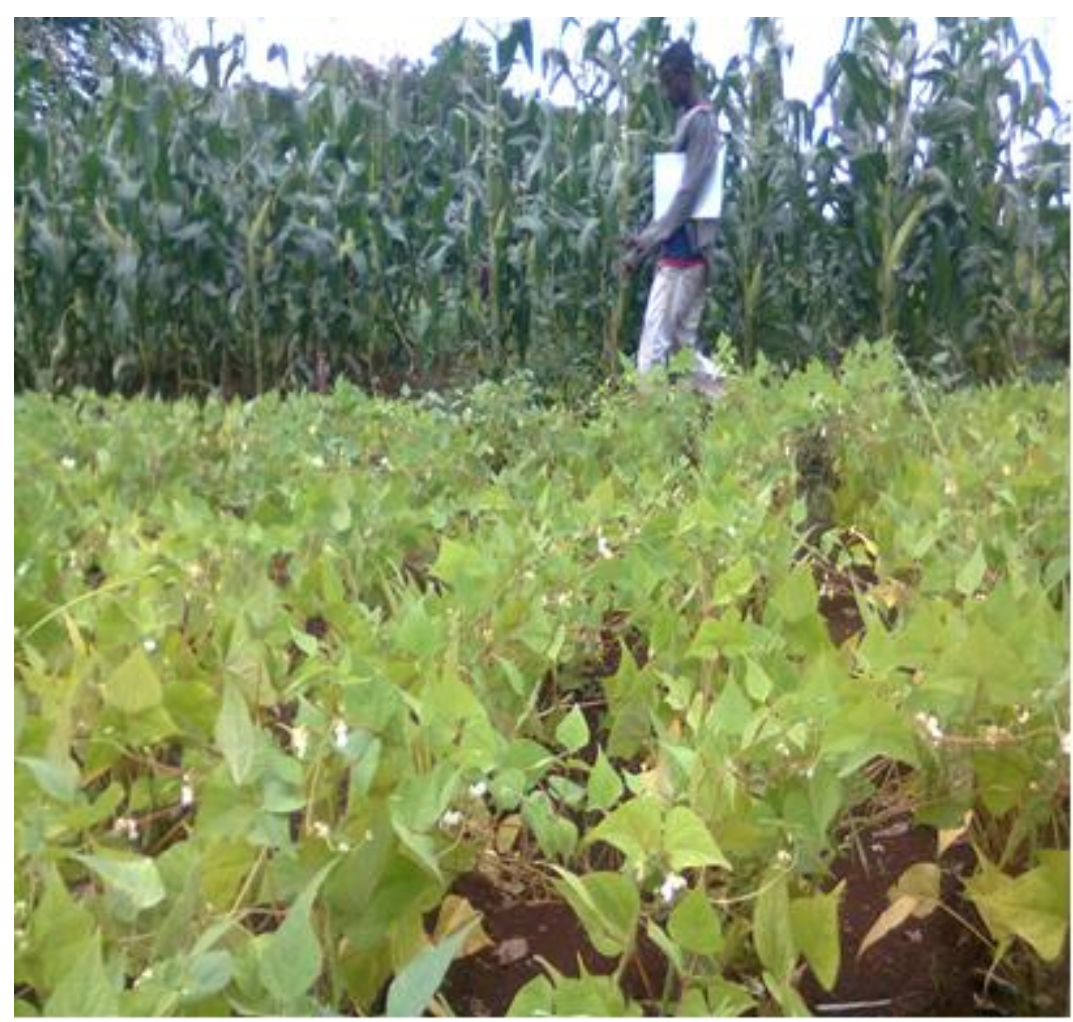

Picture 2: PARC 2013 Main Cropping season Haricot bean-Maize Intercropping

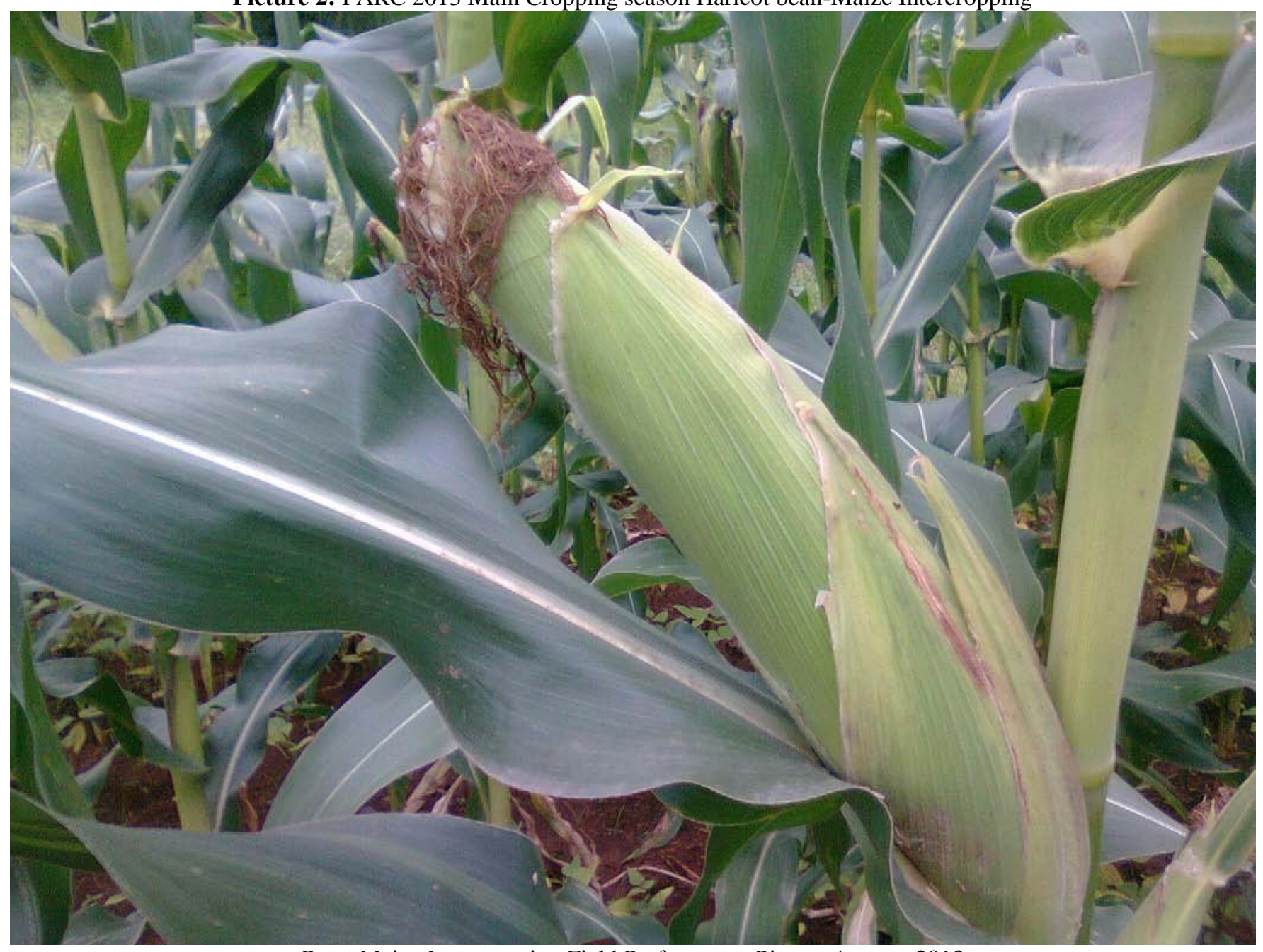

Bean-Maize Intercropping Field Performance Picture August, 2013

Volume 5 Issue 2, February 2016

www.ijsr.net 


\section{International Journal of Science and Research (IJSR) \\ ISSN (Online): 2319-7064 \\ Index Copernicus Value (2013): 6.14 | Impact Factor (2014): 5.611}

Table 4: Mean values for grain yield and its components of haricot bean in the bean -maize of two districts (Location $\mathrm{X}$ Treatment)

\begin{tabular}{|c|c|c|c|c|c|c|c|c|c|}
\hline Treatments & plht & sch & df & dm & nppp & nspp & spp & hsw & AGY(kg/ha) \\
\hline A.Melka vs BH-540 & $\mathbf{1 5 . 5} \mathbf{e}$ & $\mathbf{4 1 3} \mathbf{a}$ & $47.5 \mathrm{a}$ & $81 \mathrm{ab}$ & $2.4 \mathrm{bc}$ & $4.3 \mathrm{ab}$ & $8.4 \mathrm{bc}$ & $18.5 \mathrm{ab}$ & $343 \mathrm{ab}$ \\
\hline Awash-1 vs BH-540 & $28.5 \mathrm{bcd}$ & $177 \mathrm{a}$ & $41 \mathrm{bcd}$ & $79 \mathrm{ab}$ & $2.3 \mathrm{bc}$ & $3.5 \mathrm{ab}$ & $6 \mathrm{c}$ & $17.5 \mathrm{~b}$ & $\mathbf{2 5 4} \mathbf{~ b}$ \\
\hline Dimitu vs BH-540 & $24.3 \mathrm{~cd}$ & $32 \mathrm{a}$ & $45 \mathrm{ab}$ & $79 \mathrm{ab}$ & $2.2 \mathrm{bc}$ & $4.2 \mathrm{ab}$ & $7.5 \mathrm{c}$ & $\mathbf{2 8 . 3} \mathbf{a}$ & $419 \mathrm{ab}$ \\
\hline Nassir vs BH-540 & $20 \mathrm{~d}$ & $346 \mathrm{a}$ & $41 \mathrm{bcd}$ & $\mathbf{7 7} \mathbf{~ b}$ & $1.8 \mathrm{c}$ & $3.3 \mathrm{~b}$ & $5.5 \mathrm{c}$ & $\mathbf{2 8} \mathbf{a}$ & $500 \mathrm{ab}$ \\
\hline Awash melka & $37 \mathrm{abcd}$ & $302 \mathrm{a}$ & $43 \mathrm{bc}$ & $78 \mathrm{ab}$ & $6.9 \mathrm{abc}$ & $4.3 \mathrm{ab}$ & $\mathbf{2 8} \mathbf{a}$ & $17.5 \mathrm{~b}$ & $724 \mathrm{ab}$ \\
\hline Awash-1 & $51 \mathrm{ab}$ & $240 \mathrm{a}$ & $38 \mathrm{~cd}$ & $78 \mathrm{ab}$ & $8.2 \mathrm{ab}$ & $4.5 \mathrm{ab}$ & $24.5 \mathrm{ab}$ & $\mathbf{1 4} \mathbf{b}$ & $454 \mathrm{ab}$ \\
\hline Dimitu & $47 \mathrm{abc}$ & $195 \mathrm{a}$ & $42 \mathrm{bcd}$ & $83 \mathrm{a}$ & $\mathbf{8 . 8} \mathbf{a}$ & $\mathbf{5} \mathbf{a}$ & $\mathbf{2 9 . 5} \mathbf{~ a}$ & $19.5 \mathrm{ab}$ & $669 \mathrm{ab}$ \\
\hline Nassir & $\mathbf{6 0} \mathbf{a}$ & $370 \mathrm{a}$ & $\mathbf{3 7 . 5} \mathbf{d}$ & $\mathbf{7 7} \mathbf{~ b}$ & $6.9 \mathrm{abc}$ & $3.8 \mathrm{ab}$ & $\mathbf{2 8 . 5} \mathbf{~ a}$ & $20 \mathrm{ab}$ & $\mathbf{1 0 0 1 . 8} \mathbf{~ a}$ \\
\hline R-Square & 0.8 & 0.6 & 0.9 & 1.0 & 0.8 & 0.6 & 0.9 & 0.8 & 0.6 \\
\hline Mean & 35.4 & 295.6 & 41.7 & 78.8 & 5.0 & 4.1 & 17.2 & 20.4 & 545.6 \\
\hline
\end{tabular}

Means with the same letter are not significant different.

ANOVA mean values results of haricot bean varieties showed that there is significant differences between treatments are observed on those of plant height (511.3), days to 50\% flowering (22.1) and seeds per plant (252.2), but the rest agronomic traits showed no significance difference between treatments at $5 \%$ level of significance; in addition, location play its own role on the effect of grain yield and other agronomic traits between treatments, days to $50 \%$, days to maturity, number of pods per plant, seeds per plant and hundred seed weight are subjected to locations, but other traits are less subjected for locations (table 5).

Table 5: Overall ANOVA result for haricot bean in the bean -maize intercropping two locations (Pawe X Dibatie).

\begin{tabular}{|l|l|l|l|l|l|l|l|l|l|l|}
\hline Source of Variation & D.freedom & Plht & Sch & df & dm & nppp & nspp & spp & hsw & AGY(Kg/ha) \\
\hline Treatment & 7 & $511.3^{*}$ & $14244 \mathrm{~ns}$ & $22.1^{*}$ & $8.6 \mathrm{~ns}$ & $18.3 \mathrm{~ns}$ & $0.6 \mathrm{~ns}$ & $252.2^{*}$ & $52.3 \mathrm{~ns}$ & $116486.2 \mathrm{~ns}$ \\
\hline Location & 1 & $394 \mathrm{~ns}$ & $19182.2 \mathrm{~ns}$ & $144^{*}$ & $2550^{*}$ & $35.7^{*}$ & $0.0 \mathrm{~ns}$ & $344.1^{*}$ & $317.9^{*}$ & $27930.7 \mathrm{~ns}$ \\
\hline Error & 7 & 112.9 & 11218.3 & 4.3 & 5.8 & 6.4 & 0.4 & 48.7 & 19.2 & 83070.6 \\
\hline CV (\%) & 30.0 & 35.8 & 4.9 & 3.0 & 51.8 & 15.5 & 40.5 & 21.4 & 52.8 \\
\hline LSD(p<0.05) & 25.1 & 250.4 & 4.9 & 5.7 & 6.0 & 1.5 & 16.5 & 10.3 & 681.5 \\
\hline
\end{tabular}

Where, plht $=$ plant height, sch $=$ stand count at harvest, $\mathrm{df}=$ days to flowering,dm=days to maturity, nppp=number of pods per plant, nspp=number of seeds per pod, $\mathrm{spp}=$ seeds per plant, hundred seed weight, $\mathrm{mc}=$ moisture content and AGY= adjusted grain yield.

Based on the result which showed in table 6, there is not significantly different between treatments. Maize BH-540 combine with Dimtu scored good magnitude of grain yield (5301kk/ha) than sole maize (5200 kg/ha).

The bean varieties associated with maize showed significant different for most of the traits days to flowering , , Plant height, number of pods per plant, number of seeds per plant, hundred seed weight (table2 ). But all of the traits for
Maize showed no significant difference (table 7 and table 8). This indicates that bean yield in intercropping varies with the bean varieties used. It is important to find a compatible variety to increase production in the bean- maize intercropping. Whenever there are alternative varieties which used to cultivate in one area, it has to look also for their compatibility ability when they are intercropping with for example the common one variety.[16] indicated that crop compatibility is the most essential factor for a feasible intercropping system. Thus, the success of any intercropping system depends on the proper selection of crop species where competition between them for light, space moisture and nutrients is minimum.

Table 6: result of different traits for maize hybrid $n$ the Intercropping at Pawe on station

\begin{tabular}{|c|c|c|c|c|c|}
\hline Treatments & $\begin{array}{c}\text { Plant } \\
\text { height }(\mathrm{cm})\end{array}$ & $\begin{array}{c}\text { stand count } \\
\text { at harvest }\end{array}$ & $\begin{array}{c}\text { No. cobs at } \\
\text { harvest }\end{array}$ & field weight & $\begin{array}{c}\text { Adjusted Grain } \\
\text { Yield(kg/ha) }\end{array}$ \\
\hline A.Melka vs BH-540 & $168 \mathrm{a}$ & $42 \mathrm{a}$ & $46 \mathrm{a}$ & $10: 00 \mathrm{AM}$ & $4519 \mathrm{a}$ \\
\hline Awash-1 vs BH-540 & $178 \mathrm{a}$ & $43 \mathrm{a}$ & $49 \mathrm{a}$ & $12: 00 \mathrm{AM}$ & $4850 \mathrm{a}$ \\
\hline Dimitu vs BH-540 & $174 \mathrm{a}$ & $44 \mathrm{a}$ & $48 \mathrm{a}$ & $12: 00 \mathrm{AM}$ & $5301 \mathrm{a}$ \\
\hline Nassir vs BH-540 & $182 \mathrm{a}$ & $48 \mathrm{a}$ & $52 \mathrm{a}$ & $11: 00 \mathrm{AM}$ & $5169 \mathrm{a}$ \\
\hline Maize BH-540 & $177 \mathrm{a}$ & $45 \mathrm{a}$ & $50 \mathrm{a}$ & $12: 00 \mathrm{AM}$ & $5200 \mathrm{a}$ \\
\hline $\mathrm{cv}(\%)$ & 8.21 & 11.22 & 5.78 & 15.58 & 15.35 \\
\hline LSD $(\mathrm{P}<5 \%)$ & 27.13 & 9.36 & 5.33 & 3.28 & 1447 \\
\hline Mean & 175.6 & 44.33 & 49.07 & 11.2 & 5007.98 \\
\hline
\end{tabular}

Means with the same letter are not significantly different between treatments.

The ANOVA result showed that field weight mean separation is significantly different between treatments; but other parameters are not significantly different between treatments. Locations play very crucial role for plant height, stand count at harvest and field weight; but number of cobs at harvest and grain yield are not significantly different between two locations (table 7). 


\section{International Journal of Science and Research (IJSR) \\ ISSN (Online): 2319-7064 \\ Index Copernicus Value (2013): 6.14 | Impact Factor (2014): 5.611}

Table 7: Over all ANOVA result for maize agronomic traits in the Intercropping with Haricot bean (treatment X Location) overall result

\begin{tabular}{|l|l|l|l|l|l|l|}
\hline \multicolumn{2}{|l|}{ Agronomic Characters } & plht & sch & Ncobs & Fw & Adj.GY \\
\cline { 1 - 2 } Source of variation & d.freedom & & & & & \\
\hline Treatment & 4 & $15^{\text {ns }}$ & $7^{\text {ns }}$ & $6.4^{\text {ns }}$ & $1^{*}$ & $42997.8^{\text {ns }}$ \\
\hline Location & 1 & $1932^{*}$ & $32^{*}$ & $6.4^{\text {ns }}$ & $1.6^{*}$ & $378691.6^{\text {ns }}$ \\
\hline Error & 4 & 37 & 3.7 & 7 & 1 & 81209.8 \\
\hline CV $(\%)$ & $\mathbf{3 . 2}$ & $\mathbf{4 . 1}$ & $\mathbf{5 . 4}$ & $\mathbf{2 . 8}$ & $\mathbf{5 . 4}$ \\
\hline LSD $(p<0.05)$ & 16.8 & 5.3 & 7.5 & 0.9 & 91.2 \\
\hline
\end{tabular}

Where, plht=plant height, sch=stand count at harvest, Ncobs $=$ number of cobes at harvest, mc=seed moisture content and Adj.GY= adjusted grain yield, $*=$ significant difference at alpha 5\% \& ns= non significant.
The two locations over all mean value for all the traits showed that there is no significant difference for both sole maize $\mathrm{BH}-540$ and combination (inter-crop) maize variety. Dimtu inter crop with maize variety score highest amount of grain yield for maize $(5398 \mathrm{~kg} / \mathrm{ha})$ than sole maize $(5299.5$ $\mathrm{kg} / \mathrm{ha}$ ) across the two locations (table 8).

Table 8: Maize Grain Yield and associated agronomic traits mean result. Combined over locations

\begin{tabular}{|c|c|c|c|c|c|}
\hline Treatments & $\begin{array}{c}\text { Plant } \\
\text { height }(\mathrm{cm})\end{array}$ & $\begin{array}{c}\text { stand count at } \\
\text { harvest }\end{array}$ & $\begin{array}{c}\text { No. cobs at } \\
\text { harvest }\end{array}$ & field weight & $\begin{array}{c}\text { Adjusted Grain } \\
\text { Yield(kg/ha })\end{array}$ \\
\hline A.Melka vs BH-540 & $187.5 \mathrm{a}$ & $46 \mathrm{a}$ & $50 \mathrm{a}$ & $10 \mathrm{a}$ & $5042 \mathrm{a}$ \\
\hline Awash-1 vs BH-540 & $189 \mathrm{a}$ & $45 \mathrm{a}$ & $50 \mathrm{a}$ & $11.5 \mathrm{a}$ & $5092.5 \mathrm{a}$ \\
\hline Dimitu vs BH-540 & $191.5 \mathrm{a}$ & $45 \mathrm{a}$ & $47 \mathrm{a}$ & $11.5 \mathrm{a}$ & $\mathbf{5 3 9 8} \mathrm{a}$ \\
\hline Nassir vs BH-540 & $193.5 \mathrm{a}$ & $49.5 \mathrm{a}$ & $52 \mathrm{a}$ & $10.5 \mathrm{a}$ & $5180 \mathrm{a}$ \\
\hline Sole Maize BH-540 & $187 \mathrm{a}$ & $45.5 \mathrm{a}$ & $50 \mathrm{a}$ & $11.5 \mathrm{a}$ & $5299.5 \mathrm{a}$ \\
\hline R-Square & 0.93 & 0.80 & 0.52 & 0.93 & 0.62 \\
\hline Mean & 189.70 & 46.20 & 49.80 & 11.00 & 5202.00 \\
\hline
\end{tabular}

The highest LER recorded for Awash Melka intercropping at both Pawe (2.33) and Dibatie (1.34) locations. All intercropping in the two locations showed an advantage for the land use efficiency over the sole one. The highest relative grain yield advantage recorded by Dimtu intercropping (5932 kg/ha) and followed by Awash Melka (5819 kg/ha) (table 9).

Table 9: Maize Haricot bean Intercropping Relative Grain Yield Advantages and LER result of two districts (Pawe and Dibatie)

\begin{tabular}{|c|c|c|c|c|c|c|c|c|}
\hline & \multicolumn{2}{|c|}{ MaizeGrain Yield(kg/ha) } & Haricotbean Grain Yield(kg/ha) & \multicolumn{2}{l|}{ RYT(M+HB=Kg/ha) } & \multicolumn{2}{c|}{ LER } \\
\hline Treatments & Pawe & Dibatie & Pawe & Dibatie & Pawe & Dibatie & Pawe & Dibatie \\
\hline A.Melka vs BH-540 & 4519 a & $5565 \mathrm{a}$ & $634 \mathrm{a}$ & $254 \mathrm{~cd}$ & 5153 & 5819 & 2.33 & 1.34 \\
\hline Awash-1 vs BH-540 & $4850 \mathrm{a}$ & $5335 \mathrm{a}$ & $627 \mathrm{a}$ & $56 \mathrm{~d}$ & 5477 & 5391 & 2.31 & 1.18 \\
\hline Dimitu vs BH-540 & $5301 \mathrm{a}$ & $5495 \mathrm{a}$ & $631 \mathrm{a}$ & $173 \mathrm{~d}$ & 5932 & 5668 & 1.97 & 1.26 \\
\hline Nassir vs BH-540 & $5169 \mathrm{a}$ & $5191 \mathrm{a}$ & $627 \mathrm{a}$ & $369 \mathrm{bcd}$ & 5796 & 5560 & 1.94 & 1.23 \\
\hline Maize BH-540 (Sole) & $5200 \mathrm{a}$ & $5399 \mathrm{a}$ & & & & & & \\
\hline Awash melka (sole) & $432 \mathrm{a}$ & $814 \mathrm{~b}$ & & & & & & \\
\hline Awash-1 (Sole) & $452 \mathrm{a}$ & $281 \mathrm{~cd}$ & & & & & & \\
\hline Dimitu (Sole) & $665 \mathrm{a}$ & $707 \mathrm{bc}$ & & & & & & \\
\hline Nassir (Sole) & $631 \mathrm{a}$ & $1376.5 \mathrm{a}$ & & & & & \\
\hline
\end{tabular}

Means with the same letter are not significantly different between treatments.

Where, $\mathrm{HB}+\mathrm{M}=$ haricot bean and maize total grain yield kilogram per hectare

LER=Land Equivalent Ration

The analysis result revealed that there is a significant difference among the haricot bean for the grain yield in the over all of two locations. In terms of land equivalent ratio result, all the varieties showed comparative advantage if they will be intercropped with maize hybrid (BH-540) then they can perform than the sole cropping system. The highest land equivalent ration was obtained by Dimtu (1.64). This indicated that $64 \%$ more efficient to use Dimtu in the intercropping with $\mathrm{BH}-540$ hybrid than the sole cropping system. In addition, the relative yield advantage for Dimtu in the intercropping obtained $5817 \mathrm{~kg} / \mathrm{ha}$ (table 10). 


\section{International Journal of Science and Research (IJSR) ISSN (Online): 2319-7064 \\ Index Copernicus Value (2013): 6.14 | Impact Factor (2014): 5.611}

Table 10: Haricot bean-Maize Intercropping Compatibility Overall (Treatment X Location) Grain Yield Advantages and Land Use Efficiency

\begin{tabular}{|l|l|l|l|l|}
\hline \multicolumn{1}{|c|}{ Treatments } & $\begin{array}{c}\text { Haricotbean Grain } \\
\text { Yield(Kg/ha) }\end{array}$ & $\begin{array}{c}\text { Maize Grain } \\
\text { Yield(Kg/ha) }\end{array}$ & RYT(M+HB=kg/ha) & LER \\
\hline A.Melka vs BH-540 & $343^{\mathrm{ab}}$ & $5042^{\mathrm{a}}$ & 5385 & 1.43 \\
\hline Awash-1 vs BH-540 & $254^{\mathrm{b}}$ & $5092.5^{\mathrm{a}}$ & 5346 & 1.52 \\
\hline Dimitu vs BH-540 & $419^{\mathrm{ab}}$ & $5398^{\mathrm{a}}$ & 5817 & 1.64 \\
\hline Nassir vs BH-540 & $500^{\mathrm{ab}}$ & $5180^{\mathrm{a}}$ & 5680 & 1.48 \\
\hline Maize BH-540(Sole) & Sole Maize & $5299.5^{\mathrm{a}}$ & 5299.5 & \\
\hline Awash melka(Sole) & $724^{\mathrm{ab}}$ & & & \\
\hline Awash-1(Sole) & $454^{\mathrm{ab}}$ & & & \\
\hline Dimitu(Sole) & $669^{\mathrm{ab}}$ & & & \\
\hline Nassir (Sole) & $1001.8^{\mathrm{a}}$ & & & \\
\hline
\end{tabular}

Means with the same letter are not significantly different between treatments.

Where, $\mathrm{HB}+\mathrm{M}=$ haricot bean and maize total grain yield kilogram per hectare and LER=Land Equivalent Ration

\section{Conclusion and Recommendation}

The analysis result revealed that there is a significant difference among the haricot bean for the grain yield in the over all of two locations. In terms of land equivalent ratio result, all the varieties showed comparative advantage if they will be intercropped with maize hybrid (BH-540) then they can perform than the sole cropping system. The highest land equivalent ration was obtained by Dimtu (1.64). This indicated that $64 \%$ more efficient to use Dimtu in the intercropping with $\mathrm{BH}-540$ hybrid than the sole cropping system. In addition, the relative yield advantage for Dimtu in the intercropping obtained $5817 \mathrm{~kg} / \mathrm{ha}$. It can be drawn a conclusion that using of intercropping system for the varieties used in the study will have yield advantage than the sole cropping system.

The bean varieties which intercropped with maize hybrid showed significant different for most of the traits such as days to flowering, Plant height, number of pods per plant, number of seeds per plant and hundred seed weight. But all of the traits for Maize showed no significant difference for all varieties as well as for the sole one.This indicates that bean yield in the intercropping varies with the bean varieties used. Therefore, It is important to find a compatible variety of bean to increase production in the bean- maize intercropping.

\section{Acknowledgement}

The authors are grateful to EIAR (SIMLESA Program) for providing fund during the research period. The authors would like also to thanks Pawe agricultural research center staff for the success of this work.

\section{References}

[1] Dolijanvic Z, Kovacevic D, Oljaca S, Simic M, 2009. Types of interactions in intercropping of maize and soybean, Journal of Agricultural Sciences. 54(3): 179187.

[2] Hayder G, Mumtaz SS, Khan A, Khan S, 2003. Corn and soybean intercropping under various levels of soybean seed rates. Asian J of Plant Sci. 2: 339-341.
[3] Anil L, Phipps RH, 1998. Temperate intercropping of cereals for forage: a review of the potential for Growth and utilization with particular reference to the UK. Grass and Forage Science. 53: 301-317.

[4] Karadag Y, 2004. Forage yields, seed yields and botanical compositions of some legume- barley Mixtures under rain fed condition in semi-arid regions of Turkey. Asian Journal of Plant Science.3: 295-299

[5] Carlson D. Jonathan, 2008. Intercropping with Maize in Sub-arid Regions. Community Planning \& Analysis Technical Brief.

[6] Najafi A, mohammadi J, 2005. Study of yield and yield component on sweet corn and green bean intercropping, articles of First National Conference of legums.Mashhad.

[7] Iragavarapu TK, Randall GW, Russelle MP, 1995. Yield and N uptake of strip-intercropped, rotated corn in a ridge-tillage system. U.S. Dairy Forage Research Center. 1995 Research Summaries.

[8] Sivaraman, K. \& S.P. Palaniappan. (1996). Cropping Systems in the Tropics-Principles and Management.

[9] Montimere, M. J., B.B. Singh, F. Harris \& S.F. Blade. (1997). Cowpea in traditional cropping systems. In: Singh, B. B.; Morgan D. R.; Raji, K. E. \& Dashiell, K. E. (editors). Advances in Cowpea reearch. Pages 99113. International Institute for Tropical Agriculture (IITA) and Japan International Research Centre for Agricultural Sciences (JIRCAS), Ibadan, Nigeria.

[10]Clark, K. M. \& R.L. Myers. (1994). Intercrop performance of pearl millet, amaranth, cowpea, soybean and guar in response to planting pattern and nitrogen fertilizer.

[11]Altieri and Liebmann.1986.Insect, weed and plant disease management in multiple cropping systems.p.183-218.In C.A Francis(ed.) Multiple cropping systems. Macmillan publishing company,New York.

[12] WILLEY, R.W., 1985. Evaluation and presentation of intercropping advantages. Experimental Agriculture, v.21, p.119-133

[13] Ministry of Agriculture and Rural Develpoment (MoARD), 2011. Animal and plant health regulatory directorate. Crop Variety Register. Issue No 15.

[14] Mead, R. and Willey, R. W. (1980). The concept of a land equivalent ratio and advantages. Experimental Agriculture. 16: 217- 226.

[15] Gomez, K. A. \& A.A. Gomez. (1984). Statistical Procedures for Agricultural Research. John Wiley and Sons,New York. 


\section{International Journal of Science and Research (IJSR) \\ ISSN (Online): 2319-7064}

Index Copernicus Value (2013): 6.14 | Impact Factor (2014): 5.611

[16] Fukai, s. and B.R.Trenbath, 1993. Process determining intercrop productivity and yields of component crops. Field Crop Research, 34: 247-271.

\section{Author Profile}

Received Degree in Plant sciences from Debre Markos University, Agriculture \& Natural Resource Management Faculty; in Plant Sciences department. Currently he is a researcher in EIAR/PARC, Crop Process; Pulse, oil \& fiber crops research case team, National Soybean Research Project breeding \& genetics components. 